\title{
ANALISIS PENGGUNAAN INFORMASI AKUNTANSI DIFERENSIAL DALAM PENGAMBILAN KEPUTUSAN MEMBELI ATAU MEMBUAT SENDIRI FLA KUE SUSEN PADA DOLPHIN DONUTS BAKERY.
}

\author{
Intan Zuriati Agustina Muhamad \\ Ventje Ilat \\ Harijanto Sabijono
}

\author{
Fakultas Ekonomi dan Bisnis Jurusan Akuntansi \\ Universitas Sam Ratulangi Manado \\ email: intanz.agustina@gmail.com
}

\begin{abstract}
ABSTRAK
Dalam menjalankan usahanya setiap perusahaan selalu dihadapkan dengan berbagai macam permasalahan. Permasalahan yang timbul sangat beragam, termasuk didalamya permasalahan pengambilan keputusan. Berbagai informasi diperlukan oleh manajemen dalam memilih keputusan yang tepat. Salah satu jenis informasi yang dibutuhkan oleh manajemen sebagai dasar perencanaan dan pengambilan keputusan adalah informasi akuntansi diferensial. Analisis biaya diferensial sangat diperlukan sesuai dengan masalah yang dihadapi oleh perusahaan dalam usaha meningkatkan laba dan mengurangi kerugian, yaitu dengan mengambil keputusan apakah membuat sendiri atau membeli bahan baku. Penelitian ini bertujuan untuk mengetahui keputusan yang paling tepat yang bisa diambil oleh manajemen dalam pengambilan keputusan membeli atau membuat sendiri fla menggunakan informasi akuntansi diferensial yaitu dengan membandingkan antara biaya diferensial yang akan dikeluarkan saat membuat sendiri dan membeli dari pemasok. Hasil dari pengamatan analisis yang dilakukan pada Dolphin Donuts bakery dilihat dari biaya yang dikeluarkan menunjukkan bahwa gambaran tentang peran dari akuntansi diferensial dalam pengambilan suatu keputusan jangka pendek, dimana pihak perusahaan lebih baik membuat sendiri fla sebagai bahan baku pembuatan kue susen, karena biaya produksi yang dikeluarkan apabila membuat sendiri lebih rendah dari pada membeli dari luar.
\end{abstract}

Kata kunci : informasi akuntansi diferensial, pengambilan keputusan, membuat sendiri atau membeli

\begin{abstract}
In running a business every company always faced with many issues. There are many kinds of issues, decison making was one of them. Many informations are needed for the management in order to chose the right decision. Differential accounting information was one of the information that the management need as basis of palnning and decisions making. Differential cost analysis was appropiate for the issue in ways for the company to increase the profit and reduce the loss, which to make the decision to make or buy the material. The purpose of this research is to find out what was the right decision that the manager could took, either to make or to buy the fla using differential accounting information with comparing the differential cost within to buy or to make the fla.The result of the analysist at Dolphin Donuts bakery from differential cost showing that differential accounting information in short-term decision indicating the company better make their own fla as the material of susen, cause the production cost was more cheaper comparing if the company buy from supplier.
\end{abstract}

Keywords : differential accounting information, decision making, to make or to buy. 


\section{PENDAHULUAN}

\section{Latar Belakang}

Informasi diperlukan oleh pihak manajemen untuk mengurangi ketidakpastian dalam pengambilan keputusan. Manajemen membutuhkan informasi akuntansi diferensial ini untuk memilih altenatif tindakan yang terbaik diantara alternatif yang tersedia. Akuntansi diferensial membandingkan informasi masa yang akan datang yang berbeda untuk setiap altematif, sehingga memungkinkan manajemen perusahaan memiliki dasar yang dapat dipertanggung jawabkan dalam hal pengambilan keputusan.

Pada informasi akuntansi diferensial, umumnya manajemen menghadapi empat macam pengambilan keputusan dalam jangka pendek, yaitu membeli atau membuat sendiri, menerima atau menolak pesanan khusus, menjual atau memproses lebih lanjut suatu produk, menghentikan atau melanjutkan produksi produk tertentu atau kegiatan usaha suatu bagian perusahaan. Salah satu keputusan yang perlu diambil dalam perencanaan pada setiap alternatif adalah membeli atau membuat sendiri (make-or-buy decision) suatu komponen bahan baku. Keputusan membuat atau membeli adalah keputusan manajemen menyangkut apakah sebuah komponen harus dibuat sendiri ataukah dibeli dari pemasok luar.

Dalam membuat keputusan mengenai masalah ini, manajer harus dapat menganalisis dan mempertimbangkan dengan matang antara harga beli per unit dengan biaya produksi per unit, sehingga diperlukan data-data yang menyajikan biaya diferensial dari produk tersebut guna terhindar dari kesalahan - kesalahan dalam mengambil keputusan yang dapat mengakibatkan perusahaan akan kehilangan laba atau rugi. Saat mengambil keputusan manfaat yang didapat oleh perusahaan saat memilih sebuah alternatif harus lebih besar dari pengorbanan yang dilakukan.Untuk itu pihak manajemen harus berhati - hati dalam menentukan suatu keputusan. Kesalahan dapat terhindarkan dengan mengadakan analisa untuk memilih alternatif yang lebih baik. Hampir semua unit usaha bisa mengalami permasalahan dalam pengambilan keputusan dalam menjalani usahanya, tidak terkecuali pada Dolphin Donuts bakery, suatu usaha yang bergerak dibidang produksi berbagai jenis roti dan kue. Dalam menjalani usahanya pihak manajemen dihadapkan pada pengambilan keputusan untuk membeli atau membuat sendiri fla sebagai salah satu bahan baku pembuatan kue susen.

\section{Tujuan Penelitian}

Tujuan dilakukan penelitian ini yaitu untuk mengetahui untuk mengetahui keputusan yang paling tepat yang bisa diambil oleh manajemen Dolphin Donuts bakery dalam menggunakan informasi akuntansi diferensial membeli atau membuat sendiri fla kue susen.

\section{TINJAUAN PUSTAKA}

\section{Akuntansi Manajemen}

Ahmad (2013:5) menyatakan akuntansi manajemen merupakan penerapan teknik-teknik dan konsep yang tepat dalam pengolahan data ekonomi historikal dan dapat diproyeksikan dari suatu satuan usaha untuk membantu manajemen dalam penyusunan rencana untuk tujuan-tujuan ekonomi yang rasional dan dalam membuat keputusankeputusan rasional dengan suatu pandangan ke arah pencapaian tujuan tersebut.Informasi akuntansi manajemen disusun untuk keperluan spesifik para pembuat keputusan dan jarang disebarkan ke pihak luar organisasi. (Atkinson, et al. 2009:3)

\section{Akuntansi Manajemen sebagai Suatu Tipe Informasi}

Simamora (2012:9), Informasi akuntansi biasanya merupakan satu-satunya sumber informasi kuantitatif yang menggabungkan hasil aktivitas semua unit perusahaan. Informasi akuntansi berfungsi sebagai mekanisme integratif yang dipakai untuk mengkoordinasikan bermacam-macam aktivitas, dan sebagai suatu ukuran seluruh kinerja dan kelangsungan hidup perusahaan. Warindrani (2006:1) Informasi akuntansi adalah proses pengukuran, analisis, pencatatan dan pelaporan terhadap seluruh kejadian ekonomi yang mempengaruhi aktiva suatu perusahaan.

Halim, dkk (2013:8) Mengemukakan informasi akuntansi sebagai bahasa bisinis dikelompokkan menjadi tiga golongan, yaitu:

1. Informasi Operasi.

Data yang bersal dari informasi operasi diseleksi sesuai dengan kepada pihak mana informasi tersebut akan disajikan, serta sesuai dengan tingkat pengambilan keputusan dalam manajemen. Dalam informasi operasi ini 
sebenarnya juga mengandung informasi nonkeuangan yang banyak digunakan oleh sistem informasi akuntansi keuangan.

2. Informasi Akuntansi Keuangan

Merupakan hasil dari proses akuntansi keuangan, dan disajikan untuk pihak eksterbal perusahaan. Laporan tersebut pada dasarnya berisi mengenai posisi keuangan dan hasil yang diperoleh perusahaan secara keseluruhan. Laporan keuangan untuk pihak eksternal perusahaan dihasilkan oleh sistem informasi akuntansi keuangan.

3. Informasi Akuntansi Manajemen

Informasi akuntansi manajemen memberikan informasi (keuangan dan nonkeuangan) yang berguna untuk pengambilan keputusan manajemen. Dalam hal kebutuhan informasi keuangan, akuntansi manajemen memerlukan informasi yang lebih terinci dibandingkan dengan informasi akuntansi keuangan. Informasi akuntansi manajemen dihasilkan oleh sistem informasi akuntansi manajemen.

\section{Informasi Akuntansi Manajemen}

Informasi akuntansi manajemen sangat bermanfaat bagi manajemen terutama pada tahap penganalisaan konsekuensi setiap alternatif tindakan yang mungkin ada dalam proses pengambilan keputusan tersebut.

Halim, dkk (2013:10) menyatakan informasi akuntansi manajemen dibagi menjadi tiga tipe yaitu:

1. Informasi Akuntansi Penuh.

Akuntansi penuh menyajikan informatika mengenai pendapatan total, biaya total dan atau aktiva total baik pada masa lalu maupun masa yang akan datang, terutama yang berkaitan dengan biaya atau disebut dengan informasi akuntansi biaya penuh. Informasi mengenai biaya penuh masa lalu (historical full cost) digunakan untuk penyusunan laporan keuangan (umumnya berupa neraca dan laporan laba rugi).

2. Informasi Akuntansi Pertanggungjawaban.

Akuntansi pertanggungjawaban menyajikan informasi mengenai pendapatan, biaya atau aktiva yang dikaitkan dengan suatu bagian atau unit di dalam perusahaan. Informasi akuntansi pertanggungjawaban masa lalu bermanfaat untuk menganalisis prestasi dari masing-masing manajer pusat pertanggungjawaban. Informasi akuntansi pertanggungjawaban yang menyangkut masa yang akan datang digunakan dalam kegiatan perencanaan tahunan (anggaran/budget).

3. Informasi Akuntansi Diferensial.

Akuntansi diferensial menyajikan informasi mengenai taksiran pendapatan, biaya dan atau aktiva yang berbeda jika suatu tindakan tertentu dipilih, dibandingkan dengan alternatif tindakan lain. Informasi akuntansi diferensial berkaitan dengan masa yang akan datang.

\section{Informasi Akuntansi Diferensial}

Halim, dkk (2013:11) mendefinisikan informasi akuntansi diferensial menyajikan informasi mengenai taksiran aktiva, pendapatan, dan biaya yang berbeda jika suatu tindakan tertentu dipilih, dibandingkan dengan alternatif tindakan yang lain.

Informasi akuntansi diferensial diperlukan oleh pihak manajemen untuk pengambilan keputusan mengenai pemilihan alternatif tindakan yang terbaik diantara beberapa alternatif keputusan yang tersedia Menurut Halim, dkk (2013: 103) Informasi akuntansi diferensial terdiri dari :

1. Pendapatan diferensial

Pendpatan diferensial merupakan pendpatan yang berbeda dalam suatu kondisi, dibandingkan dengan kondiskondisi yang lain. Pendapatan masa lalu atau masa yang akan datang yang tidak berbeda diantara berbagai alternatif keputusan yang mungkin dipilih bukan merupakan pendapatan diferensial.

2. Biaya diferensial

Biaya diferensial adalah biaya yang berbeda dalam suatu kondisi, dibandingkan dengan kondisi-kondisi yang lain. Besarnya biaya diferensial dihitung dari perbedaan biaya pada alternatif tertentu dibandingkan dengan biaya pada alternatif lainnya. Darsono dan Purwanti (2009:259) menyatakan biaya diferensial yaitu biaya yang berbeda - beda akibat adanya tingkat produksi yang berbeda yang mengakibatkan perbedaan biaya tetap

3. Laba Diferensial

Erat hubungannya dengan pengertian pendapatan diferensial dan biaya diferensial. Laba diferensial adalah laba yang akan datang yang berbeda diantara berbagai alternatif yang mungkin dipilih. Besarnya laba diferensial dihitung dari perbedaan antara laba pada alternatif tertentu dibandingkan dengan laba pada alternatif lainnya. 


\section{Manfaat Akuntansi Diferensial dalam Pengambilan Keputusan Jangka Pendek}

Bustami dan Nurlela (2006:175) ada beberapa manfaat informasi akuntansi diferensial dalam pengambilan keputusan jangka pendek yang pada umumnya dihadapi oleh manajemen dalam pengambilan keputusan yang umumnya terdiri dari empat macam keputusan, yaitu :

1. Menjual atau memproses lebih lanjut ( sell or process futher )

Ada kalanya manajemen puncak dihadapkan pada pemilihan menjual produk tertentu pada kondisinya sekarang atau memprosesnya lebih lanjut menjadi produk yang lebih tinggi harga jualnya. Dalam pengambilan keputusan macam ini, informasi akuntansi diferensial yang diperlukan oleh manajemen adalah pendapatan diferensial dengan biaya diferensial jika alternatif memproses lebih lanjut dipilih.

2. Menghentikan atau melanjutkan produksi produk tertentu atau kegiatan usaha departemen tertentu ( stop or continue product line )

Dalam menghadapi kondisi ini, manajemen perlu mempertimbangkan keputusan menghentikan atau tetap melanjutkan produksinya. Dan informasi yang relevan untuk dipertimbangkan dalam pengambilan keputusan ini adalah biaya diferensial dan pendapatan diferensial.

3. Menerima atau menolak pesanan khusus ( special order decision )

Penerapan analisis biaya diferensial juga dapat digunakan untuk membuat keputusan menerima atau menolak pesanan khusus apabila kapasitas mesin perusahaan masih terdapat kapasitas yang menganggur dan pada saat itu harga jualnya dibawah harga pokok produksi dalam hitungan biaya penuh.

4. Membeli atau membuat sendiri (make or buy decision )

Pertimbangan untuk membeli atau membuat sendiri dapat juga timbul sebagai akibat adanya taksiran penghematan biaya jika suatu komponen yang sebelumnya dibeli dari pemasok luar direncanakan akan dibuat sendiri oleh perusahaan.

\section{Keputusan Membeli atau Membuat Sendiri}

Saat para manajer berusaha mengurangi biaya dan meningkatkan daya saing produknya, mereka dihadapkan pada keputusan apakah membuat produknya sendiri atau meminta perusahaan lainnya untuk menyediakan suku cadang dan komponen tersebut. Keputusan membuat atau membeli semacam ini mengilustrasikan sekali lagi cara mengidentifikasikan biaya dan pendapatan relevan. (Atkinson, et al. 2009:255)

Simamora (2012:235) menyatakan manajemen mempertimbangkan keputusan membuat atau membeli karena berbagai macam alasan, yaitu untuk:

a. Mengurangi biaya

b. Memanfaatkan atau membebaskan kapasitas

c. Memperbaiki mutu atau kinerja pengiriman

d. Mendorong produktivitas kegiatan internal yang lebih tinggi dengan memaksa persaingan dengan pihak luar

e. Mengadopsi teknologi baru

f. Membebaskan dana investasi langka bagi keperluan lainnya 
Tabel 1

Penelitian Terdahulu

\begin{tabular}{|c|c|c|c|c|c|c|c|}
\hline No. & $\begin{array}{l}\text { Nama } \\
\text { Peneliti/ } \\
\text { Tahun }\end{array}$ & Judul & Tujuan & $\begin{array}{c}\text { Metode } \\
\text { Penelitian }\end{array}$ & Hasil Penelitian & Persamaan & Perbedaan \\
\hline 1. & $\begin{array}{l}\text { Togito } \\
\text { Anita } \\
(2005)\end{array}$ & $\begin{array}{l}\text { Peranan } \\
\text { Analisis Biaya } \\
\text { Diferensial } \\
\text { dalam } \\
\text { Pengambilan } \\
\text { Keputusan } \\
\text { Membuat } \\
\text { Sendiri atau } \\
\text { Membeli Bahan } \\
\text { Baku untuk } \\
\text { Meningkatkan } \\
\text { Laba } \\
\text { Perusahaan }\end{array}$ & $\begin{array}{l}\text { Mengetahui } \\
\text { Peranan } \\
\text { Analisis } \\
\text { Biaya } \\
\text { Diferensial } \\
\text { dalam } \\
\text { pengambilan } \\
\text { Keputusan } \\
\text { Membuat } \\
\text { Sendiri atau } \\
\text { Membeli } \\
\text { Bahan Baku } \\
\text { untuk } \\
\text { Meningkatka } \\
\text { n Laba. }\end{array}$ & $\begin{array}{l}\text { Metode yang } \\
\text { digunakan } \\
\text { dalam } \\
\text { penelitian ini } \\
\text { yaitu metode } \\
\text { d eskriptif } \\
\text { analitik } \\
\text { dengan } \\
\text { pendekatan } \\
\text { survei. }\end{array}$ & $\begin{array}{l}\text { Adanya } \\
\text { hubungan } \\
\text { antara } \\
\text { analisis biaya } \\
\text { diferensial } \\
\text { dalam } \\
\text { pengambilan } \\
\text { keputusan } \\
\text { membuat } \\
\text { sendiri atau } \\
\text { membeli } \\
\text { bahan baku } \\
\text { yang } \\
\text { memadai } \\
\text { dengan laba } \\
\text { perusahaan } \\
\text { yang } \\
\text { meningkat }\end{array}$ & $\begin{array}{l}\text { Sama } \\
\text { dengan point } \\
\text { yang ditulis } \\
\text { diatas, } \\
\text { persamaan } \\
\text { dalam } \\
\text { penelitian } \\
\text { terdahulu ini } \\
\text { terdapat } \\
\text { pada topik } \\
\text { yang di } \\
\text { bahas dan } \\
\text { landaan } \\
\text { teoritis. }\end{array}$ & $\begin{array}{l}\text { Perbedaan } \\
\text { dalam } \\
\text { penelitian } \\
\text { terdahulu ini } \\
\text { yaitu penulis } \\
\text { mencoba } \\
\text { memaparkan } \\
\text { peranan biaya } \\
\text { diferensial } \\
\text { untuk } \\
\text { meningkatkan } \\
\text { laba } \\
\text { perusahaan. }\end{array}$ \\
\hline 2. & $\begin{array}{l}\text { Moha } \\
\text { mmad } \\
\text { Iqbal } \\
(2013)\end{array}$ & $\begin{array}{l}\text { Pengaruh } \\
\text { Biaya } \\
\text { Diferensial } \\
\text { terhadap } \\
\text { Proses } \\
\text { Pengambilan } \\
\text { Keputusan } \\
\text { Manajemen } \\
\text { Memproduksi } \\
\text { Sendiri atau } \\
\text { Membeli } \\
\text { Produk pada } \\
\text { PT. Fintex }\end{array}$ & $\begin{array}{l}\text { Mengetahui } \\
\text { penerapan } \\
\text { biaya } \\
\text { dierensial dan } \\
\text { Pengaruh } \\
\text { biaya } \\
\text { diferensial } \\
\text { terhadap } \\
\text { pengambilan } \\
\text { keputusan } \\
\text { membeli atau } \\
\text { memproduksi } \\
\text { sendiri } \\
\text { produk pada } \\
\text { PT. Fintex. }\end{array}$ & $\begin{array}{l}\text { Metode yang } \\
\text { digunakan } \\
\text { dalam } \\
\text { penelitian ini } \\
\text { yaitu metode } \\
\text { kuantitatif }\end{array}$ & $\begin{array}{l}\text { Dari hasil } \\
\text { penelitian } \\
\text { dengan } \\
\text { menggunakan } \\
\text { pengujian } \\
\text { hipotesis } \\
\text { menunjukkan } \\
\text { terdapat } \\
\text { pengaruh yang } \\
\text { signifikan antara } \\
\text { Biaya Diferensial } \\
\text { terhadap } \\
\text { Keputusan } \\
\text { Memproduksi } \\
\text { Sendiri atau } \\
\text { Membeli Produk. }\end{array}$ & $\begin{array}{l}\text { Persamaan } \\
\text { dari } \\
\text { penelitian ini } \\
\text { terdapat } \\
\text { pada topik } \\
\text { yang dibahas } \\
\text { yaitu } \\
\text { pengambilan } \\
\text { keputusan } \\
\text { Membeli } \\
\text { atau } \\
\text { Membuat } \\
\text { sendiri } \\
\text { produk. }\end{array}$ & $\begin{array}{l}\text { Perbedaan } \\
\text { yang } \\
\text { terdapat } \\
\text { pada } \\
\text { metode } \\
\text { penelitian } \\
\text { yaitu } \\
\text { penelitian } \\
\text { ini } \\
\text { menggunak } \\
\text { an medote } \\
\text { kuantitatif. }\end{array}$ \\
\hline
\end{tabular}

\section{Jenis Penelitian}

\section{METODE PENELITIAN}

Penulis menggunakan metode penelitian deskriptif kualitatif, yaitu metode yang menganalisis masalah dengan cara mendeskripsikannya pada data-data yang sudah ada, berupa tabel perhitungan biaya produksi untuk mengetahui perbandingan biaya produksi fla yang dapat memberikan gambaran maupun uraian jelas mengenai analisis penggunaan informasi akuntansi diferensial dalam pengambilan keputusan membeli atau membuat sendiri fla kue susen pada Dolphin Donuts bakery. 


\section{Tempat dan Waktu Penelitian}

Objek penelitian pada Dolphin Donuts bakery yang bertempat di Jl. Dr Sam Ratulangi No. 45 Manado. Perusahaan ini bergerak dibidang Restaurant dan bakery. Waktu penelitian, dimulai pada bulan september 2013.

\section{Prosedur Penelitian}

Prosedur yang digunakan penulis untuk membahas serta memecahkan permasalahan yang ada pada penelitian ini adalah teknik analisis perbandingan yang melliputi beberapa tahapan, yaitu dapat di ilustrasikan melalui gambar berikut:

1. Permohonan mengadakan penelitian pada Dolphin Donuts Bakery

2. Pengumpulan data melalui wawancara dan Observasi dengan mendatangi objek yang diteliti.

3. Mengolah data dan menginterpretasikan hasil pengolahan data.

4. Pengambilan kesimpulan berdasarkan hasil pembahasan.

5. Pemberian saran

\section{Metode Pengumpulan Data \\ Jenis Data}

Jenis data yang digunakan dalam penelitan ini adalah data kuantitaif dan data kualitatif. Data kualitatif dalam penelitan ini yaitu berupa gambaran umum perusahaan dan struktur organisasi. Sedangkan data kuantitatif dalam penelitian ini berupa data-data biaya produksi dalam perusahaan.

\section{Sumber Data}

Data primer adalah data yang diperoleh dengan survei lapangan yang menggunakan semua metode pengumpulan data original. Sedangkan data sekunder adalah data yang dikumpulkan oleh lembaga pengumpul data dan dipublikasikan kepada masyarakat pengguna data. (Indriantoro dan Supomo, 2012:146). Sumber data yang digunakan penulis dalam penelitian ini adalah dalam bentuk data primer yang merupakan data asli yang diperoleh langsung dari objek penelitian pada Dolphin Donuts bakery.

\section{Teknik Pengumpulan Data}

Untuk memudahkan pengumpulan data sehingga dapat mendekati kesempurnaan dalam penyajian, maka perlu metode yang baik, mudah dan cepat diperoleh dalam rangka penyelesaian penulisan skripsi sesuai dengan objek yang diteliti. Dengan demikian dalam penyusunan skripsi ini, penulis menggunakan beberapa metode penelitian sebagai berikut :

a) Observasi

Yaitu metode pengumpulan data yang dilakukan dengan cara terjun langsung ke objek yang diteliti dengan mengamati apa yang menjadi sasaran dalam pengambilan data sesuai dengan apa yang diperlukan.

b) Wawancara

Yaitu metode penelitian yang dilakukan dengan cara komunikasi langsung dengan pihak-pihak yang berhubungan objek penelitian dengan mengajukan pertanyaan-pertanyaan yang telah disiapkan terlebih dahulu mengenai masalah-masalah yang akan diteliti kepada pihak yang menangani pembuatan fla susen untuk mendapatkan data biaya yang diperlukan.

c) Penelitian Kepustakaan (Library Research)

Metode kepustakaan yaitu penyusunan laporan skripsi dengan cara kepustakaan. Penelitian ini dimaksudkan untuk memperoleh landasan teori guna mendukung data primer yang diperoleh selama penelitian, data ini diperoleh dari buku-buku serta referensi lainnya yang berhubungan dengan topik yang dibahas.

\section{Metode Analisis Data}

Metode analisis data yang digunakan penulis adalah metode deskriptif. Metode ini betujuan untuk memberikan gambaran keadaan perusahaan yang sebenarnya, dimana data yang dikumpulkan, disusun, kemudian dianalisis dan dijelaskan dengan teori-teori yang ada dan akhirnya membuat kesimpulan dan saran. Pada penelitian ini penulis juga menggunakan analisis kuantitatif, analisis kuantitatif yang digunakan oleh penulis adalah informasi akuntansi diferensial karena menghitung biaya produksi perusahaan, dengan cara membandingkan biaya produksi pada saat membuat sendiri fla kue susen dengan harga fla yang ditawarkan oleh pemasok. 


\section{HASIL PENELITIAN DAN PEMBAHASAN}

\section{Gambaran Umum Perusahaan}

Dolphin Donuts merupakan suatu unit usaha yang bergerak dibidang bakery dan pastry didirikan pada tahun 1 Maret 1997 oleh Bapak Hamiko Irwan. Pada awal tahun 2000 pemilik perusahaan mulai melakukan pengembangan bangunan usaha. Pembangunan berjalan lancar sehingga pada akhir tahun 2000 perusahaan sudah mulai berproduksi dengan kapasitas lebih banyak dan menambah cabang gerai counter di beberapa swalayan dan tempat lainnya, seperti Jumbo, Golden dan Gramedia. Selain memproduksi roti untuk harian perusahaan ini juga menerima pesanan khusus dengan berbagai macam cake dan roti, baik untuk acara ulang tahun, perkawinan maupun acara lainnya.

\section{Hasil Penelitian}

Dibawah ini adalah hasil perhitungan total penjualan beserta harga jual bulan Oktober 2013 yang telah diperoleh oleh penulis dari pihak Dolphin Donuts bakery sebagai berikut:

\section{Tabel 2}

Hasil Perhitungan Total Penjualan per Bulan

Total Jenis Produk
Total Unit Penjualan

\section{Total Harga Per Unit}

Total Penjualan

\section{3}

60.000

Rp. $\mathbf{5 8 7 . 5 0 0}$

Sumber: hasil olah data 2013

Berdasarkan data diatas kemudian dihitung berapa presentasi yang akan diakumulasikan untuk perhitungan harga pokok produksi pada fla khususnya pada biaya tenaga kerja langsung dan biaya overhead pabrik. Presentase tersebut dapat dihitung dengan rumus berikut:

Harga Jual Produk

Presentase Produk = $\mathrm{X} 100 \%$

Total Keseluruhan Harga Jual Produk

Setiap bulannya Dolphin Donuts bakery memproduksi 6000 unit susen dengan harga per unit yaitu Rp.4.500. Jadi total penjualan susen perbulannya yaitu Rp. 27.000.000. Maka presentasi penjualan untuk menghitung harga pokok produksi fla kue susen dapat dihitung sebagai berikut:

$$
\text { Rp. } 27.000 .000
$$

Presentase fla kue susen $=$

$$
\text { Rp. } 702.150 .000
$$

\section{Biaya produksi}

Berikut akan dijelaskan perincian biaya yang harus dikeluarkan oleh perusahaan untuk pembuatan fla yang diperlukan untuk memberi isi di dalam kue susen untuk persediaan selama 1 bulan yang datanya diambil pada bulan oktober 2013. Fla yang diperlukan untuk mengisi 6.000 buah susen adalah sebanyak $480 \mathrm{~kg}$. Rincian biaya tersebut adalah sebagai berikut:

\section{Tabel 3}

Biaya bahan baku fla

\begin{tabular}{llcc}
\hline \multicolumn{1}{c}{ Nama Bahan } & \multicolumn{1}{c}{ Harga Satuan } & Banyaknya & Jumlah Biaya \\
\hline Susu Segar & Rp. 11.000/Liter & 30 Liter & Rp. 330.000 \\
Susu Kental Manis & Rp. 6.500/Kaleng & 30 kaleng & Rp. 195.000 \\
Telur & Rp. 15.000/Lusin & $50 \mathrm{Lusin}$ & Rp. 750.000 \\
Tepung & Rp. $7.000 / \mathrm{kg}$ & $75 \mathrm{Kg}$ & Rp. 525.000 \\
Gula Pasir & Rp. $12.000 / \mathrm{kg}$ & $60 \mathrm{Kg}$ & Rp. 720.000 \\
Margarin & Rp. 20.000/kg & $24 \mathrm{Kg}$ & Rp. 480.000 \\
\hline & Total Biaya Bahan Baku & & Rp. 3.000.000 \\
\hline
\end{tabular}

Sumber: Dolphin Donuts bakery, Oktober 2013 


\section{Biaya Tenaga Kerja Langsung}

Dolphin Donuts bakery memiliki delapan orang pekerja dibagian produksinya yang bekerja berdasarkan tugas masing-masing total gaji yang dibayarkan khusus untuk tenaga kerja langsung yaitu Rp.12.000.000. Berdasarkan presentase harga jual yang telah dihitung sebelumya yaitu 3,8\% maka jumlah biaya tenaga kerja yang dikeluarkan untuk membuat persediaan fla kue susen selama 1 bulan adalah :

$\operatorname{Rp} 12.000 .000 \times 3.8 \%=\operatorname{Rp} 456.000$

\section{Tabel 4}

Rincian biaya tenaga kerja langsung khusus pembuatan fla kue susen

\begin{tabular}{ccc}
\hline Keterangan & $\begin{array}{c}\text { Jumlah } \\
\text { tenaga kerja }\end{array}$ & Biaya per bulan \\
\hline Koki Pembantu & 2 & Rp. 152.000 \\
Baker & 4 & Rp. 228.000 \\
Pembantu & 2 & Rp. 76.000 \\
\hline Total & 8 & Rp 456.000
\end{tabular}

Sumber: hasil olah data 2013

\section{Biaya Overhead Pabrik} lurus.

Berikut adalah rincian Biaya Overhead Pabrik, dimana untuk biaya penyusutan menggunakan metode garis

a) Biaya bahan bakar gas yang digunakan selama satu bulan yaitu Rp 4.550.000

b) Biaya listrik yang dibayarkan setiap bulannya sebesar Rp 13.000.000

c) Biaya pulsa telepon setiap bulannya sebesar Rp 500.000

d) Biaya sewa bangunan setiap bulannya sebesar $\mathrm{Rp} 8.333 .333$

e) Biaya penyusutan perlengkapan pabrik setiap bulan mengunakan metode rata-rata:

- Penyusutan mixer $=4.000 .000 \div 12$ bulan $=333.333 /$ bulan

- Penyusutan oven $=16.800 .000 \div 12$ bulan $=1.400 .000 / \mathrm{bulan}$.

- Penyusutan cooler $=18.0000 .000 \div 12$ bulan $=1.500 .000 /$ bulan

Total Biaya penyusutan perlengkapan pabrik yaitu sebesar Rp. 3.233.333

f) Biaya karyawan tetap

Total gaji yang dibayarkan untuk karyawan tetap setiap bulannya yaitu sejumlah Rp. 26.000.000

Berdasarkan uraian diatas maka dapat diketahui total jumlah biaya overhead pabrik yang dikeluarkan oleh pihak perusahaan untuk proses prodsi perbulannya adalah:

- Biaya bahan bakar gas $\quad$ : Rp. 4.550 .000

- Biaya listrik : : Rp.13.000.000

- Biaya telepon $\quad$ : Rp. 500.000

- Biaya sewa bangunan $\quad$ : Rp. 8.333 .333

- Biaya penyusutan perlengkapan pabrik $\quad$ : Rp. 3.233 .333

- Biaya karyawan tetap $\quad: \underline{\text { Rp.26.000.000 }}$

\section{Total biaya overhead pabrik $\quad$ Rp.55.616.666}

Presentase biaya overhead yang dikeluarkan oleh perusahaan khusus untuk produksi fla kue susen perbulannya yaitu sejumlah

Rp. 55.616.666 x 3.8\% = Rp. 2.113.433,3

Berikut adalah rincian akumulasi biaya overhead pabrik khusus untuk memproduksi fla kue susen setiap bulannya berdasarkan presentase $3.8 \%$ 
Tabel 5

Biaya overhead pabrik khusus pembuatan fla kue susen

\begin{tabular}{lc}
\hline \multicolumn{1}{c}{ Keterangan } & Jumlah \\
\hline Biaya bahan bakar gas & Rp. 172.900 \\
Biaya listrik & Rp. 494.000 \\
Biaya telepon & Rp. 19.000 \\
Biaya sewa bangunan & Rp. $316.666,7$ \\
Biaya penyusutan perlengkapan pabrik & Rp. $122.866,6$ \\
Biaya karyawan tetap & Rp. 988.000 \\
\hline \multicolumn{1}{c}{ Total biaya overhead pabrik } & Rp. $\mathbf{2 . 1 1 3 . 4 3 3 , 3}$
\end{tabular}

Sumber: hasil olah data 2013

\section{Perhitungan HPP fla membuat sendiri}

Harga Pokok Produksi fla susen Oktober 2013

\section{Biaya bahan baku}

- Susu Segar

- Susu kental manis

- Telur

- Tepung

- Gula pasir

- Margarin

Total bahan baku langsung

Rp. 330.000

Rp. 195.000

Rp. 750.000

Rp. 525.000

Rp. 720.000

Rp. 480.000

Rp. 3.000.000

2. Biaya Tenaga Kerja Langsung

- Koki Pembantu

Rp. 152.000

- Baker

Rp. 228.000

- Pembantu

Rp. 76.000

\section{Biaya Overhead Pabrik}

$$
\text { Total BTK Langsung }
$$

- Biaya bahan bakar gas

- Biaya listrik

- Biaya telepon

$$
\text { Rp. } 172.900
$$

Rp. 19.000

- Biaya sewa bangunan

Rp. $316.666,7$

- Biaya peny. perlengkapan pabrik

- Biaya karyawan tetap

Rp. 988.000

Total biaya overhead pabrik Total Harga Pokok Produksi

Sumber: hasil olah data 2013

$\frac{\text { Rp. } 2.113 .433,3}{\text { Rp. } 5.569 .433,3}$

Jadi berdasarkan perhitungan yang telah dilakukan di atas, untuk memproduksi fla sebanyak $480 \mathrm{~kg}$ peruahaan perlu mengeluarkan biaya sebesar Rp. 5.569.433,3 atau kurang lebih Rp. 11.600 per kilogram fla.

\section{HPP fla jika Membeli dari Pemasok}

Alternatif selain membuat sendiri fla peruahaan bisa membeli dari pemasok luar. Ada beberapa pemasok yang menawarkan fla sebagai bahan baku pembuatan kue susen kepada perusahaan dengan harga yang beragam, pemasok juga menawarkan untuk mengantarkan fla langsung ke pabrik persahaan jadi pihak perusahaan bisa menghemat biaya angkut. Harga beli per kg fla yang ditawarkan oleh pemasok rata-ratanya adalah sebesar Rp. 20.000,-. Jadi jika peusahaan memutuskan untuk membeli fla dari pemasok maka untuk memenuhi kebutuhan fla perbulannya yaitu sebanyak 480kg fla perusahaan perlu mengeluarkan total biaya sejumlah Rp. 9.600.000. 


\section{Pembahasan}

Perbandingan biaya jika membuat sendiri dan membeli sendiri menggunakan analisis biaya diferensial. Dalam pengambilan keputusan membuat sendiri atau membeli dari luar fla tersebut informasi akuntansi yang relevan adalah dengan menggunakan biaya diferensialnya, dapat dilihat dari tabel di bawah ini :

Tabel 6

Perbandingan Biaya Differensial Membeli atau Membuat Sendiri

\begin{tabular}{lcc}
\hline \multicolumn{1}{c}{ Keterangan } & Membuat Sendiri & Membeli \\
\hline Biaya bahan baku & Rp. 3.000 .000 & \\
Biaya tenaga kerja langsung & Rp. 456.000 & \\
Biaya overhead pabrik & Rp.2.113.433,3 & \\
Harga Beli & & Rp. 9.600.000. \\
\hline Total Biaya Diferensial & Rp. 5.569.433,3 & Rp. 9.600.000. \\
\hline Penghematan Biaya & Rp. $\mathbf{4 . 0 3 0 . 5 6 6 , 7}$ & \\
\hline
\end{tabular}

Sumber: hasil olah data 2013

Berdasarkan perhandingan biaya diferensial yang telah disajikan pada tabel diatas, diketahui bahwa ada beberapa biaya diferensial yang muncul saat perusahaan memilih alternatif untuk membuat sendiri yaitu, biaya bahan baku langsung, biaya tenaga kerja langsung dan biaya overhead pabrik. Total biaya yang akan dikeluarkan oleh pihak perusahaan jika memutuskan untuk membuat sendiri fla kue susen setiap bulannya yaitu senilai Rp. 5.569.433,3 atau sebesar Rp. 11.600 per kilogramnya. Sedangkan biaya yang akan dikeluarkan oleh pihak perusahaan jika memilih alternatif untuk membeli dari pemasok yaitu sejumlah Rp. 9.600.000 atau sebesar Rp. 20.000 perkilogramnya.

Dari perbandingan analisis akuntansi diferensial menggunakan biaya diferensial dapat diputuskan bahwa perusahaan lebih baik memilih untuk membuat sendiri fla, karena dengan membuat sendiri fla susen perusahaan dapat menghemat biaya sebesar Rp. 4.030.566,7 atau sebesar Rp 8.600 untuk tiap $1 \mathrm{~kg}$ fla.

\section{PENUTUP}

\section{Kesimpulan}

Dari penelitian yang sudah dilakukan, dapat disimpulkan bahwa keputusan yang lebih baik diambil oleh pihak manajemen Dolphin Donuts bakery adalah membuat sendiri fla kue susen karena biaya yang dikeluarkan lebih kecil atau lebih hemat jika dibandingkan dengan membeli dari pemasok.

Setiap bulannya untuk memproduksi $480 \mathrm{~kg}$ fla, biaya yang dikeluarkan adalah sebesar Rp. 5.569.433,3 atau sejumlah Rp. Rp. 11.600 per kilogramnya, sedangkan apabila perusahaan membeli dari luar maka biaya yang dikeluarkan sebesar Rp. 9.600.000 atau sejumlah Rp. 20.000 per kilogramnya sehingga akan timbul selisih penghematan biaya perusahaan sebesar Rp. 4.030.566,7 atau sejumlah $\mathrm{Rp} 8.600$ untuk setiap $1 \mathrm{~kg}$ fla jika persahaan memilih untuk membuat sendiri fla kue susen. Dengan demikian diketahui bahwa biaya diferensial yang diperoleh oleh Dolphin Donuts bakery jika membeli fla dari pemasok luar lebih besar dibandingkan dengan jika perusahaan membuat sendiri.

\section{Saran}

Pihak manajemen Dolphin Donuts bakery sebaiknya mengambil keputusan untuk membuat sendiri fla mengingat biaya yang dikeluarkan lebih rendah daripada membeli dari luar karena lebih menguntungkan dan juga dapat melakukan penghematan biaya. Selain itu keuntungan lain membuat sendiri perusahaan bisa lebih menjaga mutu, rasa serta kualitas dari fla yang dibuat. 


\section{DAFTAR PUSTAKA}

Ahmad, Kamaruddin. 2013. Akuntansi Manajemen: Dasar-dasar, konsep, biaya dan pengambilan keputusan. Edisi Revisi ke Delapan. RajaGrafindo Persada. Jakarta.

Atkinson, Anthony., Kaplan, Robert R., Matsumura, Ella Mae., Young, S Mark. 2009. Akuntansi Manajemen. Jilid Satu. Edisi ke Lima. Indeks. Jakarta.

Bustami, Bastian., Nurlela. 2006. Akuntansi Biaya, Melalui Pendekatan Manajerial. Mitra Wancana. Yogyakarta.

Darsono, Prawironegoro., Purwanti, Ari. 2009. Akuntansi Manajemen. Edisi ketiga. Mitra Wacana Media. Jakarta.

Halim, Abdul., Bambang, Supomo., Kusufi, Syam Muhammad. 2013. Akuntansi Manajemen. Edisi ke Dua. BPFE. Yogyakarta.

Indriantoro, Nur., Supomo, Bambang. 2012. Metodologi Penelitian Bisnis Untuk Akuntansi Manajemen. BPFE . Yogyakarta.

Mohamad, Iqbal. 2013. Pengaruh Biaya Diferensial terhadap Proses Pengambilan Keputusan Manajemen Memproduksi Sendiri Atau Membeli Produk. Skripsi. Universitas Pasundan. Cirebon. http://diglib.unpas.ac.id/download-mohammadiq-2650-1-skripsi.pdf

Simamora, Henry. 2012. Akuntansi Manajemen. Edisi ke Tiga. Star Gate Publisher. Riau.

Togito, Anita. 2005. Peranan Analisis Biaya Diferensial dalam Pengambilan Keputusan Membuat Sendiri atau Membeli Bahan Baku Untuk Meningkatkan Laba Perusahaan. Jurnal. Universitas Widyatama. Bandung.. http://repository.widyatama.ac.id/xmlui/bitsream/handle/10364/1065/cover.pdf

Warindrani, Armila Krisna. 2006. Akuntansi Manajemen. Graha Ilmu. Yogyakarta. 